\title{
Selected ecological settlements
}

\author{
Merve Küçük ${ }^{1}$, Fehim Findik ${ }^{2 *}$ \\ ${ }^{1}$ Faculty of Architecture, Gebze Technical University, 41400 Gebze/Kocaeli, Turkey \\ ${ }^{2}$ Metallurgy and Materials Engineering Department, Faculty of Technology, Sakarya Applied Sciences University, 54187 Sakarya, \\ Turkey
}

*Corresponding author: findik@sakarya.edu.tr

Pbstract
Published by ARDA.
Today, the use of fossil-based fuels and construction activities on a global and
regional scale have effective climatic and environmental consequences all over the
world, leading to disruption of living spaces. For this reason, it is important that the
structures have sustainable properties that will reduce environmental impacts
throughout the entire life cycle. Millions of people go to various countries and
become refugees due to world wars and migrations. Here, ecological settlements
and the criteria for the settlement are needed in order to make these settlements
healthy. The ecological settlements in Turkey (Gaziantep, Bursa and Eskisehir) as
well as in the world (China, Germany and Spain), listed the criteria that are
necessary for these places, are revised in this review article.

Keywords: Refugee; Ecology; Ecologic Living Unit; Ecologic Settlement; Settlement Criteria

\section{Introduction}

Insensible consumption of natural resources on a global and regional scale causes important environmental problems such as increased greenhouse gas emissions, global warming, depletion of the ozone layer, climate change and ecosystem degradation. Construction activities play an important role in the formation of these problems. For this reason, it is important that the structures have sustainable properties that will reduce environmental impacts throughout the entire life cycle. In order for the ecological settlement to be applicable, a sample region can be selected by taking the opinions of the relevant municipalities. The climatic and environmental characteristics of the selected region and their functions according to vegetation should be taken into consideration. In order to provide data for all this study, literature search can be made, and sample ecological campus projects in the world should be evaluated. As a result of the research, an ecological living unit model for the use of refugees in an area deemed appropriate and design decisions that take into account environmental data for the eco settlement consisting of these units should be made. The ecological settlements in Turkey (Gaziantep, Bursa and Eskisehir) as well as in the world (China, Germany and Spain), listed the criteria that are necessary for these places, are revised in this review article.

\section{Ecological settlements}

Ecological and sustainable planning is an improved planning approach that aims to prevent the natural environment from being considered as a source of consumption and to produce its own energy with the least harm to the environment. Sustainable settlements emerging with this understanding are not only settlements where ecological values are considered, but also a whole with their social and economic components. Various ecological settlement approaches have been created with environmental values gaining importance. The main 
purpose of ecological settlements is to construct or use the existing in a way that is compatible with the natural balance and to have the least impact.

\subsection{Ecological settlement planning approaches}

The ecological settlement models and planning approaches that emerged since the 1990s are as follows; New urbanization movement, compact city, ecological cities, smart growth, slow cities, ecovillage and smart cities. New Urbanism: The purpose of the New Urbanism movement that emerged in the late 1980s in America can be described as creating more accessible, compact and livable cities. In this context, the current states that the settlements should be built together with the environment, not independently of the environment, but in an integrated manner. Basically, the New Urbanism movement can be walked, axes that provide easy connection with each other, mixed use and diversity, public space, excessive public spaces, open spaces and parks where social interaction is provided, diversity instead of a single type of residence, quality architecture and urban design, traditional settlement structure, it is shaped around the main elements such as sustainability, smart transportation, quality of life. In this case, factors such as the access to social facilities and different city centers are easier, bicycle and pedestrian transportation is common, instead of settling in untouched lands, the selection of lands close to urban settlements in order to protect these areas, reduces the impact of the natural environment. Thus, the growth rates of the cities are taken under control and all planning and investments are made according to this understanding.

Compact City: The compact city has four characteristic features. First of all, compact cities should have more sustainable and efficient transportation systems. Because compact cities have a high population density and a land structure that allows mixed use, living and working spaces are not far from each other. Secondly, compact cities allow the use of a sustainable space by reducing the spread of space. Thus, while the rural area is protected, the soil in the city center has a recyclable quality for different purposes. Third, the concepts of social structure, density and mixed use; it is handled together with the concepts of cultural development - unification and diversity. This also provides justice in the city, because the opportunities are accessible to everyone. Finally, the supply and quality of urban infrastructure has a more economical quality [1].

Eco-City: Urban ecology first came to the agenda with the International Eco-City Conference held in Berkeley, California in 1990. The conference focused on urban sustainability issues and encouraged more than 700 participants to offer suggestions on how cities work best in environmental ways. In 1992, Richard Register founded the organization Eco-City Builders, which plays an important role in the sustainability of eco-cities. The goal of the eco-city is to produce energy from completely renewable sources by removing all carbon waste, harmonizing the city with the natural environment, promoting economic growth, reducing poverty and increasing efficiency as much as possible.

Smart Growth: The term smart growth was introduced in 1997 by the governor of Maryland Parris Glendening to prevent urban sprawl. Majorities, such as California, Connecticut, New Jersey, New York, Massachusetts, Maryland, Pennsylvania, North Carolina, Virginia, which have grown with this propagation trend until the 90s, have turned towards reform in comprehensive planning policies, at least 100 smart growth. The related law has been defined in 27 states [2]. Principles of smart growth concept, combined land uses; benefit of compact building designs; diversity in housing opportunities and choices; walking areas; spaces that are developed, distinctive and attractive and create a strong sense of place; environmental zones devoted to protected agricultural and open spaces, natural beauty; strengthened and developed settlements; diversity in transportation options; future-oriented, fair and cost-effective developments; public participation constitutes communityshareholder cooperation [2].

Slow City: Cittaslow (Slow city); It is formed by the combination of the words "Citta (City)" in Italian and "Slow (Slow)" in English and is used to mean "Calm City". It is known as part of the Slow Movement. This movement is a union that towns and cities, which do not want to be one of the similar places formed as a result of globalization, want to be recognized in the world by preserving their local identity and features. The slow 
urban approach was born from slowing down the rate of change and keeping these local features alive without losing their unique identity with global capital and urbanization tendencies. It is based on the protection and survival of the features in the ecological and sustainability area existing in the traditional structures of the cities. As an attitude towards cities that resemble each other with globalization and lose their local characteristics, it is an urbanization policy that preserves the traditional life style and emphasizes local identity rather than the "fastfood" culture where local products are consumed [3].

Ecovillage: Ecovillage concept was first used with Solheimar Eco-village established in Iceland in 1930s. Ecovillages supports sustainable, autonomous, collective and productive life intertwined with nature and emerges as a solution against global economic dependence [4]. The main principles of Ecovillage:

- To grow food in the bio-area of the community as much as possible,

- To support organic food production in this area,

- Making houses from local materials,

- By combining village-based, renewable energy systems,

- To protect biological diversity,

- To stick to ecological business principles,

- To evaluate the life cycle of all products used in Ecovillage socially, mentally and ecologically,

- Keeping soil, water and air clean with proper energy and waste management,

- To protect nature and preserve wilderness areas [5].

Smart City: Smart city can be defined as the application of technology to cities for a sustainable life and urbanization. The most emphasized technological solutions are; water management, clean and renewable energy, smart traffic control, e-government, urban mobility, wireless internet accessibility and waste management can be counted as solutions [6]. In this context, smart cities can be interpreted as controlling global cities in an environmentally sensitive manner through technology. It is to meet the needs of the population living in the cities with its smart infrastructure and social equipment, with its smart design compatible with the environment, to increase the quality of the environment, to carry out public services such as health, education and transportation regularly with smart management and to provide secure urban living spaces with the help of information technologies.

While the principles of planning and design meet in the idea base of adapting the ecological settlement to nature, ecological settlement currents emerged with the differentiation of methods. In Table 1, environmental, social and economic criteria of these flows are compared.

Table 1. Sustainable settlement models [7]

\begin{tabular}{l|l|l|l}
\hline \multicolumn{1}{c}{ Planning and Design Principles } \\
\hline -Environmentally friendly & \multicolumn{1}{c}{ Social } & \multicolumn{1}{c}{ Economy } & \multicolumn{1}{c}{ Name } \\
placement & -Places designed on & -Various typologies in & New Urbanism \\
-Production of energy from & -Specific & the residences - & \\
renewable sources & architectural design & & \\
- Efficient use of water & & & \\
- Compact form in layout & & & \\
- Mixed use of land & & & \\
- Spring-accessible settlement & & & \\
- Defined region borders and & & & \\
settlement & & & \\
\hline
\end{tabular}




\begin{tabular}{|c|c|c|c|}
\hline \multicolumn{4}{|c|}{ Planning and Design Principles } \\
\hline Environmental & Social & Economy & Name \\
\hline $\begin{array}{l}\text {-Compact form in layout } \\
\text { - Mixed use of the land } \\
\text { - Low energy consumption } \\
\text { - Sustainable transportation } \\
\text { systems } \\
\text { - Protection of rural areas }\end{array}$ & - Urban justice & $\begin{array}{l}\text {-Economic urban } \\
\text { infrastructure }\end{array}$ & Compact City \\
\hline $\begin{array}{l}\text { - Protection of air quality } \\
\text { - Infrastructure compatible } \\
\text { with nature } \\
\text { - Environmental awareness } \\
\text { - Production of energy from } \\
\text { renewable sources } \\
\text { - Sustainable transportation } \\
\text { systems }\end{array}$ & -Cultural awareness & $\begin{array}{l}\text { - Cost-effective eco- } \\
\text { engineering solutions }\end{array}$ & Eco-city \\
\hline $\begin{array}{l}\text { - Compact structure form } \\
\text { - Wasable settlements } \\
\text { - Protection of the natural } \\
\text { environment } \\
\text { - Mixed use of the land } \\
\text { - Development in existing } \\
\text { residential area borders }\end{array}$ & $\begin{array}{l}\text {-The sense of } \\
\text { belonging in the } \\
\text { settlement } \\
\text {-Cooperation in } \\
\text { society }\end{array}$ & $\begin{array}{l}\text { - Cost effective } \\
\text { development } \\
\text { - Different housing } \\
\text { types }\end{array}$ & Smart Growth \\
\hline $\begin{array}{l}\text { - Energy efficiency and waste } \\
\text { management } \\
\text { - Use of renewable energy } \\
\text { systems } \\
\text { - Prevention of noise, light, } \\
\text { electromagnetic pollution } \\
\text { - Promoting pedestrian, } \\
\text { cycling and public } \\
\text { transportation }\end{array}$ & $\begin{array}{l}\text {-Protection of } \\
\text { historical and } \\
\text { cultural values } \\
\text { - Design for the } \\
\text { disabled }\end{array}$ & $\begin{array}{l}\text { - Supporting the local } \\
\text { economy }\end{array}$ & Slow City (Cittaslow) \\
\hline $\begin{array}{l}\text { - Organic farming -Green } \\
\text { construction techniques } \\
\text { - Recyclable material use } \\
\text { - The goal of reducing the } \\
\text { ecological footprint }\end{array}$ & $\begin{array}{l}\text {-Voluntary } \\
\text { participation } \\
\text { - Common spiritual } \\
\text { values }\end{array}$ & $\begin{array}{l}\text { - Economically being } \\
\text { able to afford yourself }\end{array}$ & Eco-village \\
\hline $\begin{array}{l}\text { - Adaptation to the } \\
\text { environment } \\
\text { - Sustainable development } \\
\text { goals } \\
\text {-To produce solutions to } \\
\text { ecological problems with } \\
\text { technology }\end{array}$ & & & Smart City \\
\hline
\end{tabular}


In addition to all these new and sustainable urbanization models, human-scale settlements should be planned to create livable spaces on a smaller scale. Designs directed by buildings and streets, where appropriate comfort conditions are provided within the buildings, urban access areas are combined, healthy building designs are developed and materials can be reused and that apply green building standards. Principles determined and developed by the American Institute of Architects (AIA) in defining a habitable settlement system are as follows [8];

\section{Human scale design}

To create a pedestrian-friendly society that can walk from compact dwellings to shopping places, institutions, cultural venues and businesses. To help reduce traffic while benefiting human health.

\section{$>$ Providing options}

Settlements, where many activities are combined, increase people's satisfaction. The combination of various places such as housing, recreation area, transportation, business, shopping makes that campus livable.

\section{$>$ Editing multiple uses}

Bringing together the places used for different purposes enables the formation of mobile pedestrian-friendly communities that respond to the need.

\section{$>$ Protecting city centers}

It is ensured that the gaps in the city center are filled and street texture is formed, order is ensured and new infrastructure needs are prevented. This approach prevents the city from spreading, revitalizes the city and supports its sustainability.

\section{$>$ Various transportation options}

To give people the options of walking, cycling, using public transportation. In addition to driving, it aims to reduce the traffic density, and to organize physical activities by protecting the environment.

\section{Building live public areas}

Urban residents need areas where they will have a good time in the city. Urban participation areas that increase human relations should be organized.

\section{Creating a neighborhood identity}

The texture of a neighborhood is its unique character. The most important feature of a neighborhood is that all the necessary places are within walking distance.

\section{$>$ Protecting environmental resources}

Well-designed settlements support maintaining natural balance, aim to protect environmental systems, protect water resources from pollution, reduce air pollution.

\section{Protecting the landscape}

It is important in terms of open spaces, farms, wildlife habitats, recreation areas and cultural values.

\section{$>$ Design}

Designs in which all the details are considered form the basis of successful and healthy societies.

Ecological settlements show that the scale should be ecologically and environmentally sensitive rather than a structure that is ecological alone, whether small or large. A residential area should contain systems that produce 
its own energy, can provide transportation on foot, and convert its waste, so that environmental awareness takes part in the social life of the user mass as part of daily life. The values that disappear as we move from rural to urban life reappear with the ecological life system. In ecological settlements, people who protect the environment, are a part of common life, cooperate, act and therefore communicate with more people.

Ecological settlement practices with such important benefits are becoming more and more widespread as a new planning approach in the world and in our country. Some of these examples are presented in the section 2.2.

\subsection{Ecological settlement examples}

Sustainable ecological settlements, despite the fact that we come across as an urban planning approach, offer a new lifestyle and is a model that has a close relationship with management. The characterization of a settlement as an eco-city often happens with the support and support of the local government of the settlement.

Nowadays eco-city projects in Turkey, with the encouragement of Bursa Nilüfer Municipality Nilüfer Eco-city, Gaziantep, Kilis, Gaziantep Metropolitan Road is the Eco-city, with the encouragement of the municipality. These two projects are in the process of implementation [7].

When ecological settlements are realized with sustainable design criteria, "sustainable" buildings bring awareness to the environment by creating closeness to the environment and its users, as well as the countless increases to be achieved in terms of resource use, environmental effects and wastes; draws attention to the relationship between buildings and consumption materials and natural resources and waste. It also reminds us that we can live in harmony and respect for the natural environment [9]. In this section, we will talk about exemplary ecological settlement projects that aim and implement sustainable design criteria.

\section{Ecological settlement samples from Turkey}

\section{Gaziantep eco-city}

Gaziantep is Turkey's $6^{\text {th }}$ largest city and it has a population of about $1,850,000$; population growth rate ranks 2nd in the country. Gaziantep industry, trade, tourism, transportation junction region etc. is rapidly urbanizing with its potentials and its population is increasing. Meeting the needs of the growing population is possible with planned development. When the zoning plan and development pressures are examined in the form of the city macro, the pressure of the mass housing areas in the Gaziantep Kilis Road Region in the southwest of the city causes uncontrolled and irregular secondary housing impairments in the structure of the region. For this reason, it is important to make a modern, pioneering and exemplary ecological planning that protects and strengthens the rural character of the area.

With the Gaziantep Kilis Road and Environment Vision Plan prepared, sustainable use of natural resources, protecting ecological balance, soil, water and air quality, maintaining plant and animal diversity, improving organic agriculture, ensuring efficient and efficient use of energy, and continuity of green area and ecological targets have been determined. In social goals, various cultural structures and vision components have been determined that will make the region the focal point. Cultural, ecological and recreated areas considered for ecological settlement are shown in Figure 1.

An incentive mechanism has been created to ensure that the construction in the Eco-city area is ecological, environmentally friendly, requires minimum energy, is well insulated, is managed by wastes, can provide the necessary energy for heating and lighting with natural and active systems, and that protects and / or improves the green texture on the land to be built. To the extent that these criteria are met, $30 \%$ larger structures can be constructed [10]. 


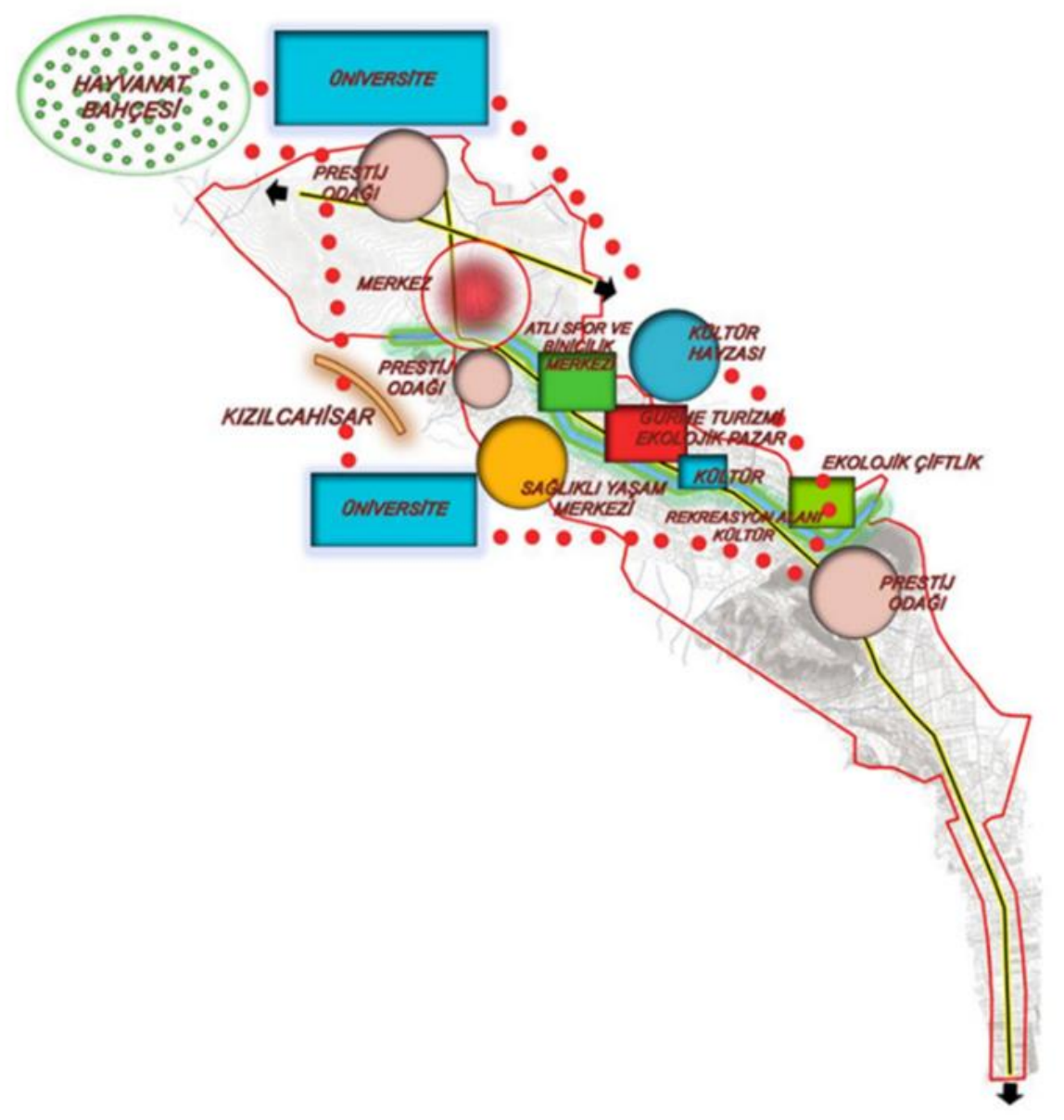

Figure 1. Gaziantep eco-city settlement planning [10]

A planning model that provides views to each residential unit and is compatible with the topography is shown in Figure 2 ( $a$ and $b$ ). The valley property of the area has been preserved, in line with the opinions of the Provincial Directorate of Agriculture, construction in the vineyard-garden order on the green texture of the valley floor and low, medium and high-density residential areas in hilly areas are planned. Ventilation corridors were created by constructing green areas with continuity in the area.

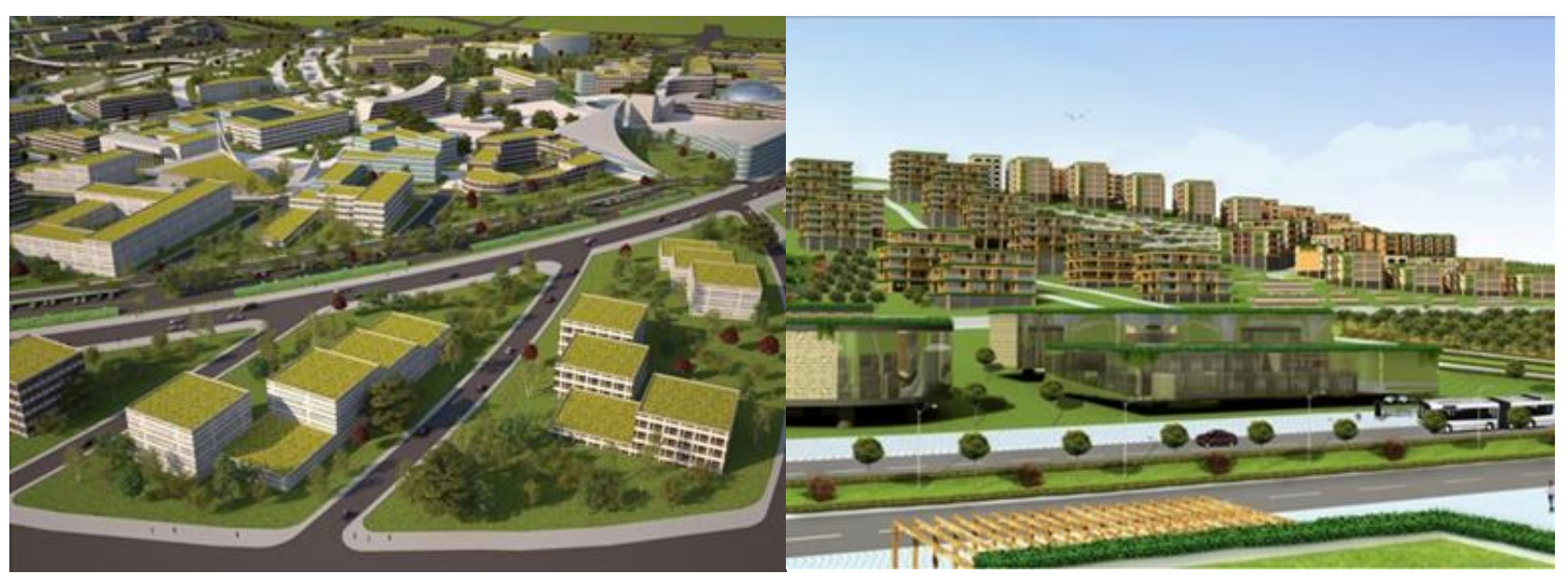

Figure 2 (a and b). Gaziantep eco-city 3D exterior visuals [10] 


\section{Nilüfer eco-city (Bursa)}

Bursa, both in terms of population size is Turkey's 4th largest city with added value to the national economy. To date, it has been described in many different ways; "Industrial city", "historical city", "cultural city" and "agricultural city" are among these. Today, "Eco-City" tries to add one of the important international urban development approaches to these definitions.

In this project, within the borders of Nilüfer Municipality, on the south of Bursa-İzmir highway, it has been approved independently and partially applied in approximately 2,200 hectares of land, at different scales. Zoning Plans such as the Master Plan; Reorganization in a planning approach that takes ecological sensitivities and aims urban integrity in a functional sense is shown in Figure 3.

In the new planning study, a new settlement pattern that is more compatible with the natural environment and functionally integrated was proposed. While Bursa-Nilüfer Eco-City is planned;

- The concept of neighborhood seen in the upper scale in Figure 4 ( $a$ and b) and the components of the neighborhood

- Pedestrian

- Sensitivity about natural thresholds and compliance with the environment

- Strong connections with intense activity areas in Bursa center

- Integrated transportation systems

- Compliance with the environment

-The principles of Life and Work unity and functional self-sufficiency were emphasized [11].

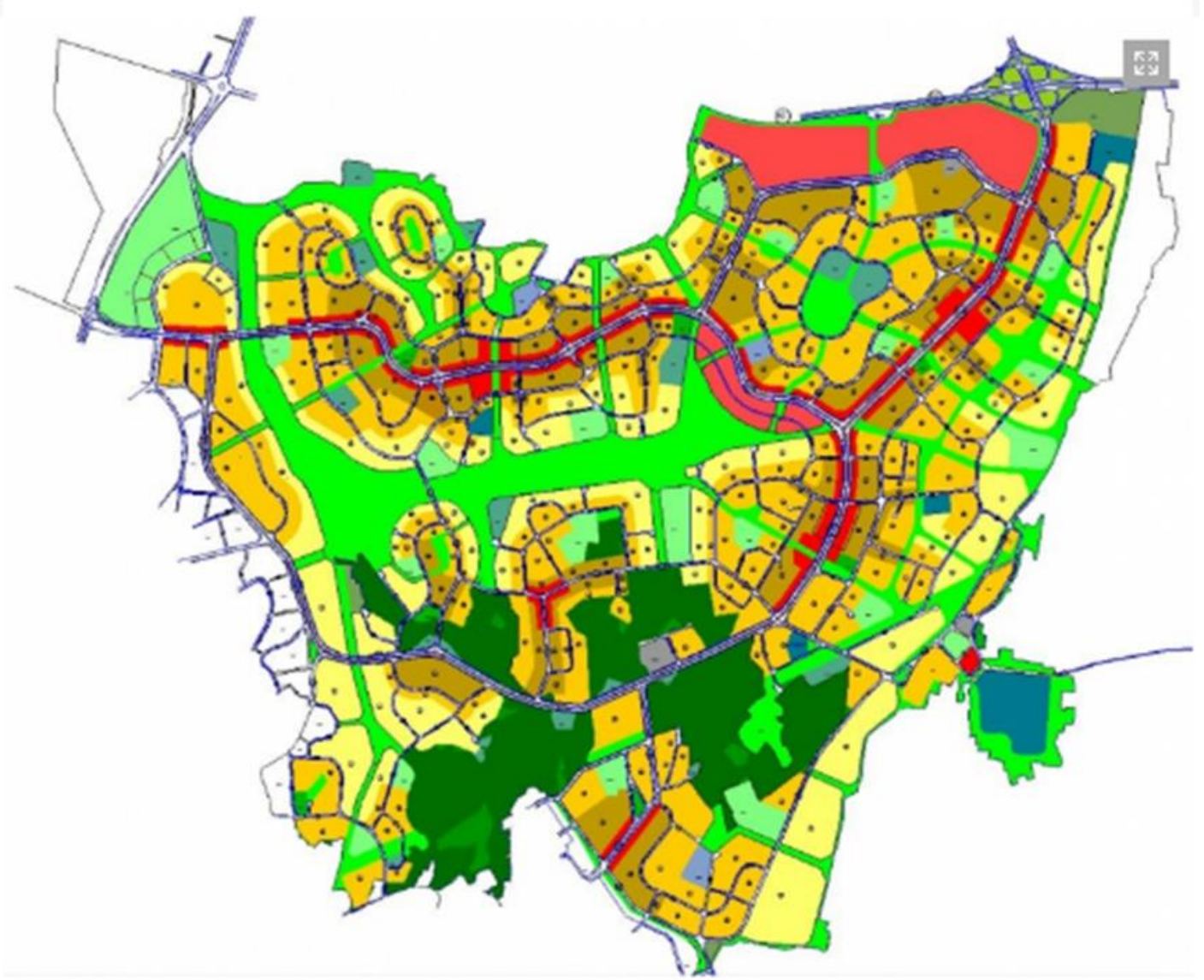

Figure 3. Nilüfer eco-city Master Plan [11] 


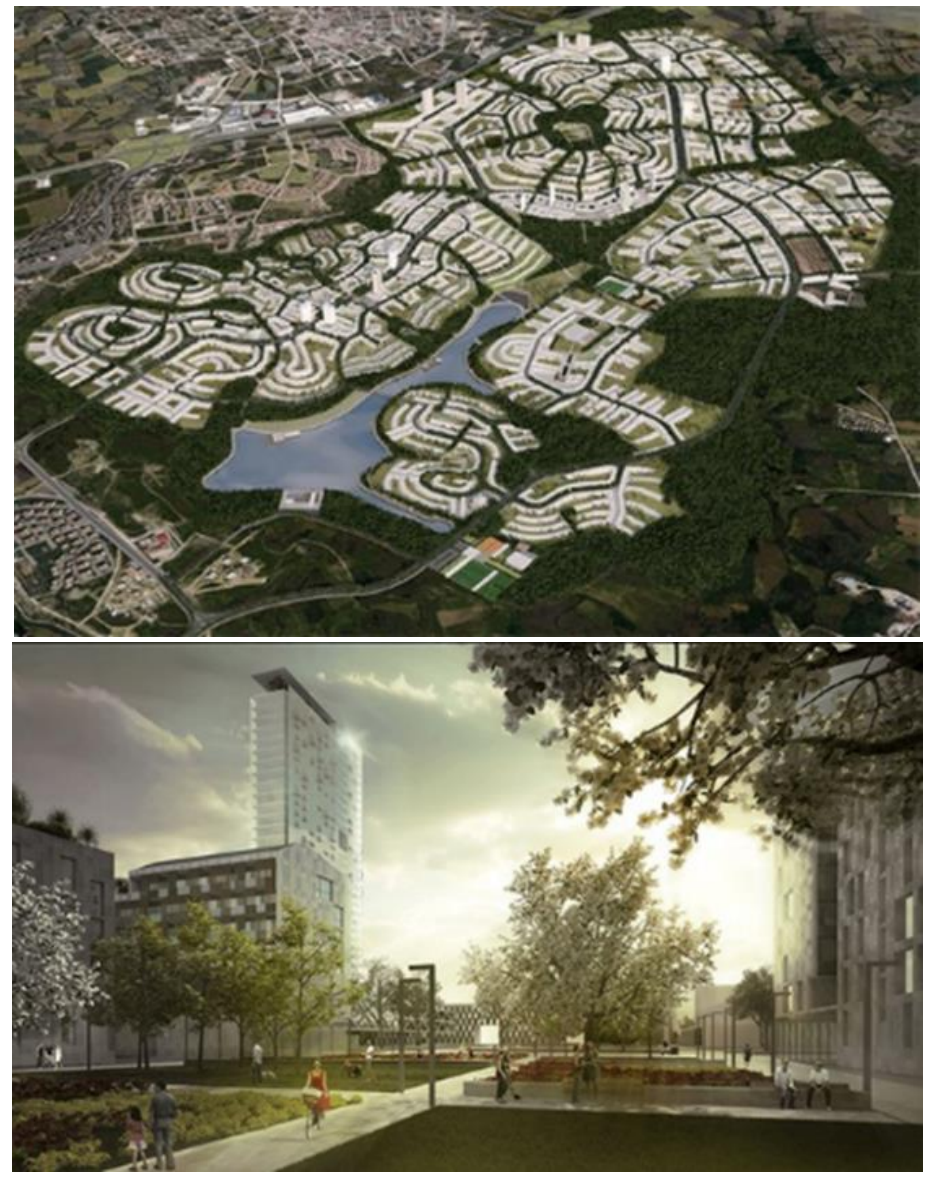

Figure 4 (a and b). Nilüfer eco-city general perspective and boulevard [12]

\section{Kocakır eco-city (Eskişehir)}

The aim of the ecological city approach is to take precautions against the negative effects of the changing world order and to try to ensure the continuity of its living and inanimate existence by creating healthy living spaces. The Kocakır Eco-city planning and design concept goals formed around this aim; to reduce urban waste and carbon emissions, to generate energy, to use renewable energy sources, to strengthen the relationship between the city and the environment, to provide economic growth, to reduce poverty, to design the city as high density provided that it remains acceptable [13].

In addition to the efforts to adapt to climate change, targets such as "increasing the resistance against disasters, reducing the heat island effect, reducing carbon emissions, maintaining biodiversity, supporting local / organic food production, supporting sustainable energy production and increasing energy saving" are the main targets of ecological settlement planning. The Kocakır ecological settlement area has been planned as in Figure 5 and the regional heating and cooling system proposed within this settlement area has been designed to allow the use of renewable energy sources. Accordingly, the cogeneration plant is planned close to the biomethanization plant, agricultural waste processing plant and waste water treatment plant. Thus, besides natural gas and solar energy, organic wastes (biomethanization), agricultural wastes (the facility where pre-separation and processing is made) and methane gas (gas to be obtained from wastewater treatment plant) to obtain energy from agricultural wastes coming from the region and outside the region can be used as energy raw material. In addition, it is aimed to further reduce natural gas consumption with additional activities such as the production of methane gas, which can be used instead of natural gas by utilizing the domestic and agricultural wastes of the region, and growing trees to benefit from the chips in the region. The system is intended to be installed in a smart grid structure. 
Thus, it is aimed to be monitored and managed remotely at the distribution system, stations, supply lines and consumer level. In the ecological settlement planned for 75.000 people in a gross area of 838 ha, the gross density was calculated as approximately $90 \mathrm{ki} /$ ha and the net density was calculated as $370 \mathrm{ki} / \mathrm{ha}$. Figure 6 (a and b) shows the neighborhood units and recreation area. The project has an average of $91 \mathrm{~m}^{2}$ of green space per capita and the average number of floors is 6-8 floors [13].

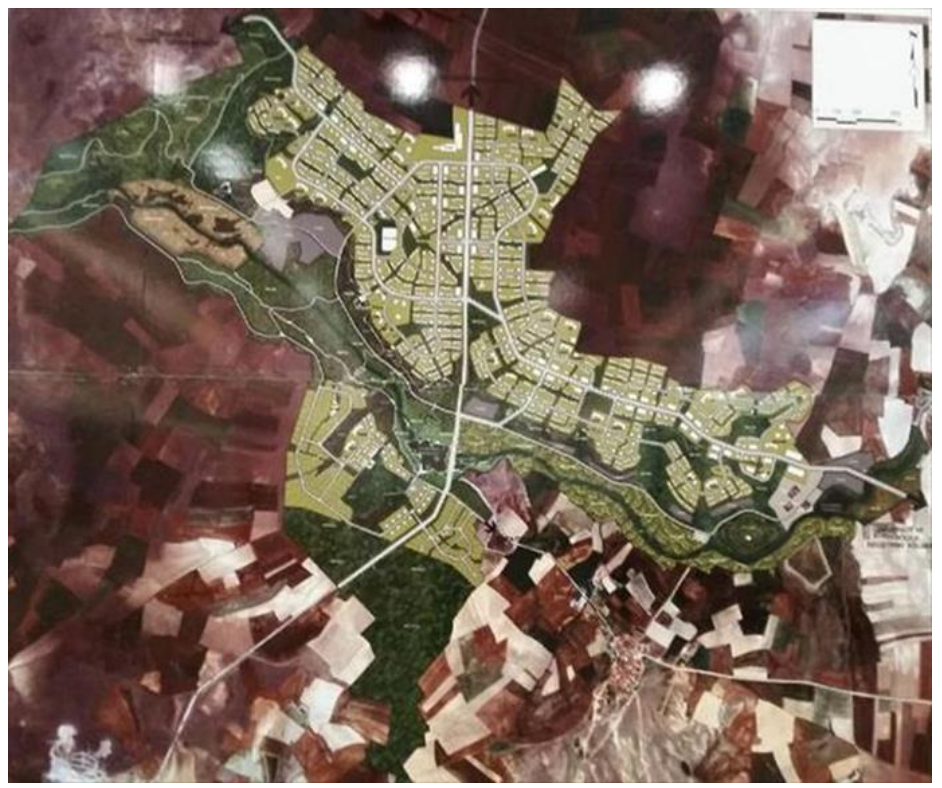

Figure 5. Kocakır eco-city settlement planning [14]

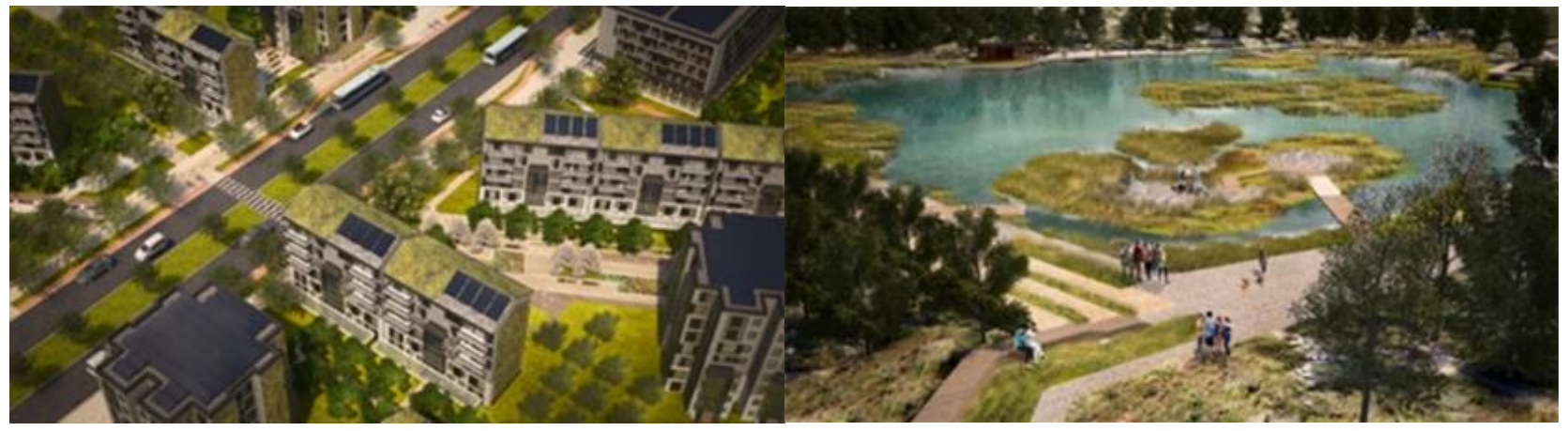

Figure 6 (a and b). Kocakır eco-city neighborhood units and recreation area [12]

\section{Ecological settlement examples from the world Tianjin eco-city (Singapore-China)}

The China-Singapore Tianjin Eco-City Master Plan tries to strike a balance between essential needs, including social, economic and environmental needs. It was developed jointly by the Chinese Urban Planning and Design Academy, Tianjin Urban Planning and Design Institute, and the Singapore planning team led by the Urban Development Administration (URA).

The planning principles of Tianjin Eco-City, whose layout plan is shown in Figure 7, are as follows:

$>$ Land use planning

The eco-city is planned to be compact based on Transit Focused Development principles, which includes a good mix of land uses. Each region has business opportunities nearby. Local and central facilities serve the needs of 
those living in each neighborhood (Figure 8 (b)). Each district is served by city centers. Business parks are located near residential areas to provide employment for residents.

Plan transportation planning

The emphasis on green transport is a key feature in Eco-city's transportation planning. The aim is to increase travel through eco-free public transport and non-motorized transport such as cycling and walking. To achieve this, non-motorized and motorized networks will be separated to minimize conflict between pedestrians, cyclists and vehicles. The transportation network in the eco city is planned to give priority to pedestrians, non-motorized transport and public transport.

$>$ Green and blue network planning

The eco-city is planned with large green (vegetation) and blue (water) nets to provide a comprehensive living and working environment. The green network will include a green lung in the center of the Eco-city and green relief eco-corridors that spread from the lung to other parts of the Eco-city. The water bodies in the ecological city seen in Figure 8 (a) will create more water circulation to improve ecology and provide an attractive environment for water-based recreational activities. The Eco-City Management Committee has rehabilitated a wastewater pool and turned it into a clean and beautiful lake [15].

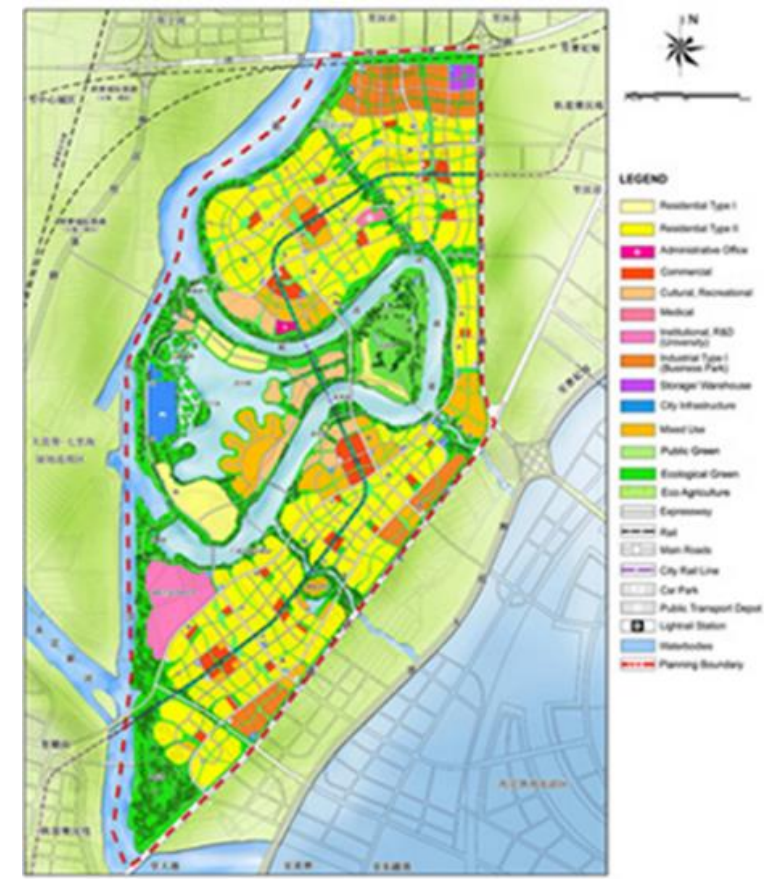

Figure 7. Tianjin eco-city layout plan [15]
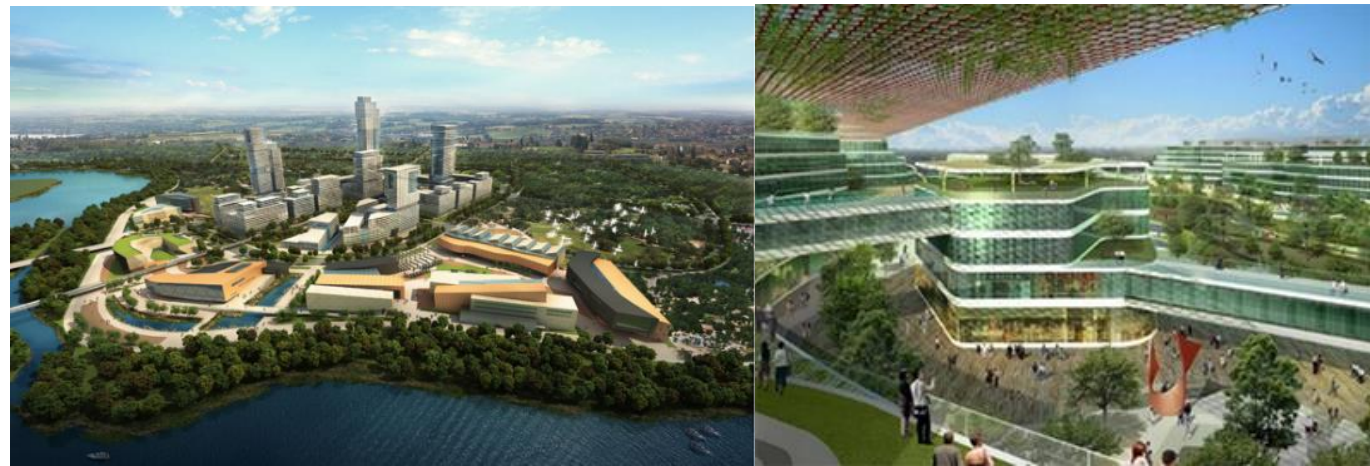

Figure 8 (a and b). Tianjin eco-city 3D images [12] 


\section{Vauban eco-city (Germany)}

Freiburg's Vauban region is one of the best examples of the world's sustainable urban life in southern Germany. The region was planned around the green transport environment (another city known as a global sign of green city planning, such as Curitiba in South Brazil), because transport as well as consumption is important for reducing ecological impacts. While the neighborhood has streets, cars almost never pass and are not suitable for parking lots. Pedestrian and bicycle paths create a highly connected, efficient, green transportation network with every home within walking distance and all schools, businesses and shopping centers within walking distance.

The 42 building units have the Passivhaus standard, consuming below $15 \mathrm{kWh} / \mathrm{m}^{2} .100$ houses comply with the "plus energy" standard, generate more energy than they use, sell the surplus back to the city grid and generate dividends between each household. In Figure 9 ( $a$ and b), the arrangement of roof solar panels, one of the sources that provide energy production, with energy saving neighborhood units with a compact solution is shown. Each building in Vauban has solar panels on its roof.

Organic household wastes are treated with an anaerobic digester. The place contains a unique ecological sewage system in a pilot project: absorbed with vacuum pipes, feces are transported to this digestion and biogas used for cooking is produced. Gray water is cleaned in biofilm plants and returns to the water cycle [16].

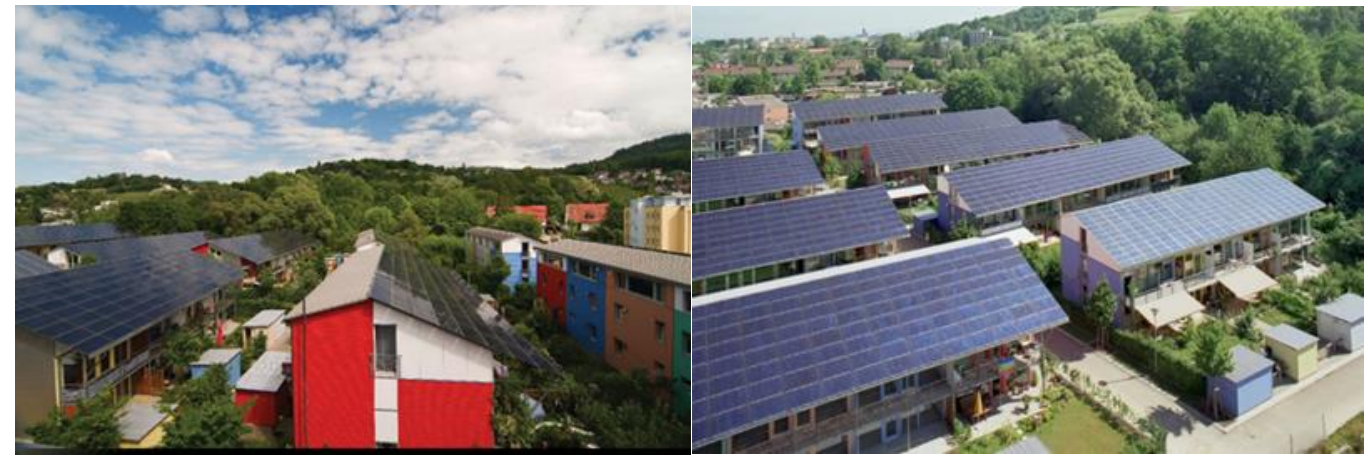

Figure 9 ( $\mathrm{a}$ and b). Vauban eco-city settlement general view [17]

\section{Sociopolis (Spain)}

Sociopolis promotes urbanization without a traditional urban form. Irrigated agricultural land outside Valencia creates an open interface between the city and huerta (one of the traditional agricultural areas surrounding Valencia city), as shown in Figure 10, providing social relationships, interaction, functional complexity and the creation of green spaces and opportunities. Sociopolis proposes to create an urban area that will move before the park to an open metropolitan area, which should contain a significant portion of the huerta.

In this project, urban transformation is supported by the commitment to provide the highest protection for the existing huerta, which is irrigated with the waters of the Turia River, which was irrigated, firstly, through the channels scraped by the Arabs. Figure 11 ( $a$ and $b$ ) shows the regions where urban agriculture will be made. While the new urban development strengthens the protection of the landscape and the environment, it also aims to deliver the housing to a large number of people at a controlled price by fulfilling a much-needed social function.

There are four well-preserved historic farmhouses in the neighborhood, which will be the focal points of the 'urban farm' areas maintained by local residents. Sociopolis is based on two principles: the first is that the issue of livability cannot be solved by building houses only, but must be dealt with simultaneously at various scales 
from the residential cell to the city; the second is the need to reorganize the principles of urbanism in response to the need for interaction between urban and rural areas to create new habitats today.

To this end, it avoids proposing an abstract scheme that will extend the underdeveloped adjacent urban structure, and instead is based on the principle that the development of the agricultural structure (and associated historical irrigation channels) in the allocated sector can be maintained through the establishment of the conservation system.

The neighborhood will also improve social interaction and community sense through sports facilities such as football pitch, athletics track, playgrounds and ice-skating rink.

All of the proposed buildings, the central complex, which has a surface area of $120,000 \mathrm{~m} 2$, has direct access to the transportation routes around it.

In addition to the residential blocks and towers, the neighborhood will have buildings with a mixed schedule in which the public life of the neighborhood will be organized. Public buildings will have rented accommodation for young people aged 30 and under, and at the same time, all buildings will fulfill their public professions through programs that promote social relations such as an art center and kindergarten. Studios will be created for sports fields, social centers, youth centers and artists [18].

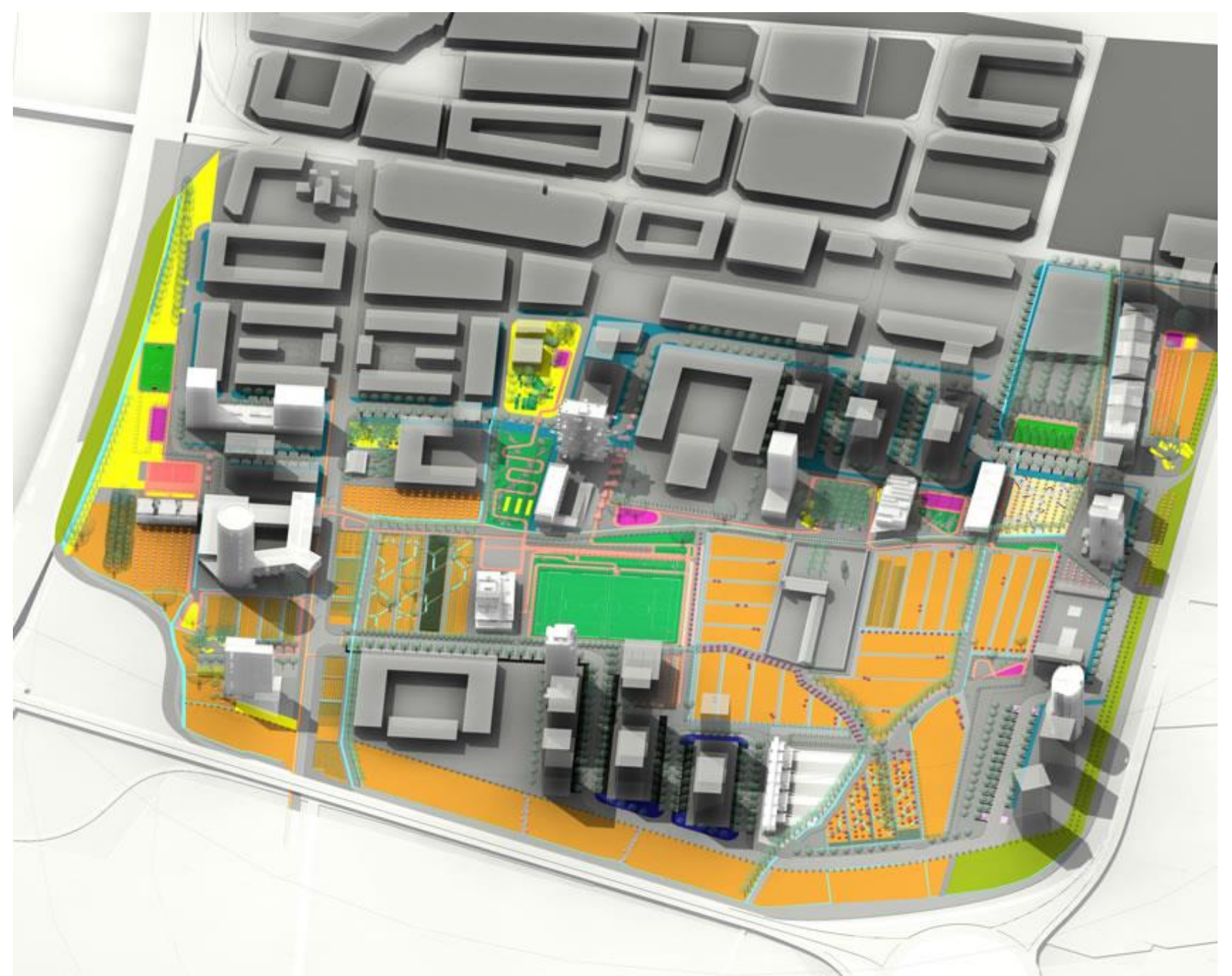

Figure 10. Sociopolis layout plan [18] 


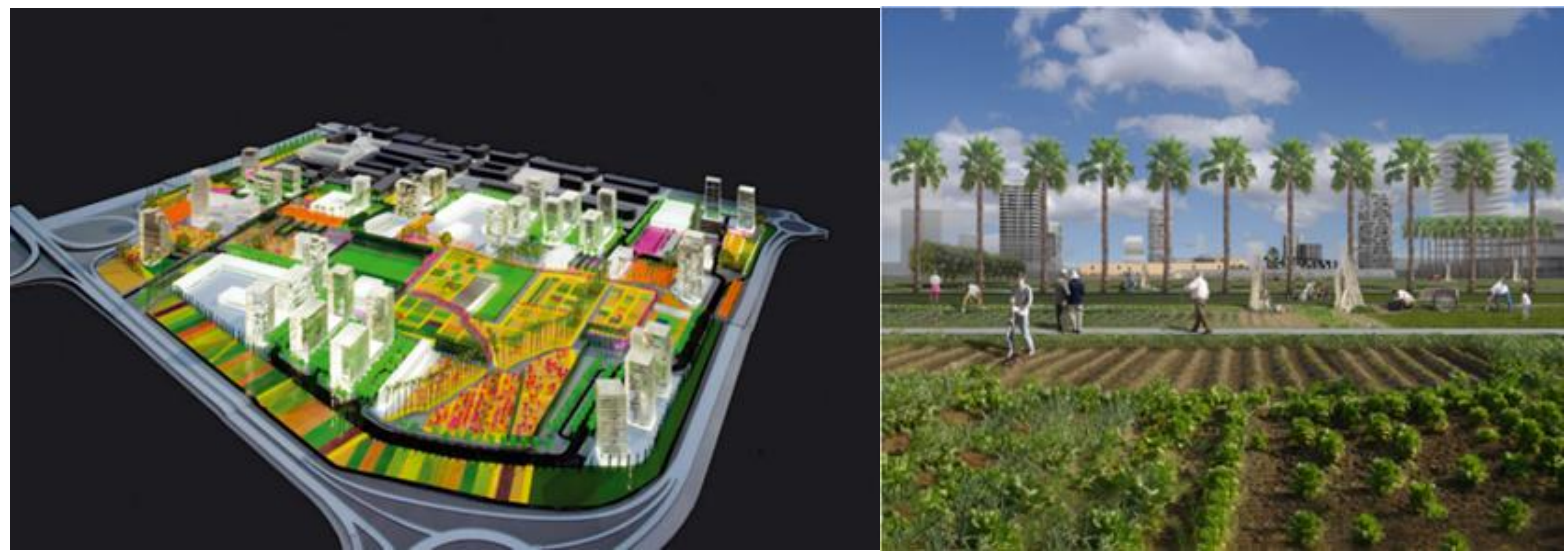

Figure 11 (a and b). Sociopolis 3D settlement and urban agriculture visual [18]

\subsubsection{Section evaluation}

According to the evaluation results obtained by examining the ecological settlements; Turkey had been including more examples of ecological residential urban renewal projects and environmental steps taken towards improving the current situation. The first example of this is the Kocakir eco-city, which has been selected as the pilot region, with the "super-city" criteria set out with laws supporting energy conservation. In Kocakır eco-city, adaptation to environmental data, compact construction and transportation by pedestrian, bicycle and hybrid vehicles are provided. In addition, energy will be obtained from domestic waste along with sustainable natural resources. In this way, it shows zero energy, zero waste and a self-sufficient eco-city. Regarding the efficient use of natural resources and energy, buildings in the Vauban city project, which is one of the examples in the world, are designed to consume the least amount of energy. With the photovoltaic panels, the surplus of electricity needed from the sun is transferred to the city's electricity grid. In the Tianjin eco-city project, rainwater is accumulated in a pond, allowing it to be reused in activities such as garden irrigation, and the pond features a natural recreation area as part of the landscape. In the Sociopolis project, ecology and technology were brought together on a common ground. A source database has been created in the city and a digital communication network has been created. Examples include comparisons between the most important considerations: ecological residential projects both in Turkey and the world, it is designed to adapt to environmental data and topography. The transportation system is provided by pedestrians and bicycles in order to minimize carbon dioxide emissions. Specially to encourage pedestrianization, residences and businesses have been designed close to each other. Green areas are considered as recreation areas or urban agricultural areas, and ecological settlements maintain the green area ratio to a large extent and ensure the continuity of natural life. However, the principles of protecting the environment and minimizing the ecological footprint in the natural environment are the main features of the ecological settlements, just as the buildings compensate for the place they cover on the ground with a green roof. When ecological and sustainable settlement examples are examined, it is seen that the projects are built on many different design parameters $[19,20]$. These differences, which make the architecture unique, are thanks to the semantic bond that the building establishes with its location. Local and regional priorities increase the richness and diversity of architectural design.

\subsection{Ecological settlement criteria}

In this section, the ecological settlement design criteria are listed based on the examination of the sample ecological settlements and the literature research.

\section{A. Compliance to local tissue \\ B. Compliance with topography \\ C. Venue organization}

- Design according to local culture 
- User health and efficiency

- Special semi-open / open space design

\section{Energy conservation}

- Suitability for regional climate

- Compact planning and compact form in the layout

- Proper orientation and positioning of structures

- Adequate natural lighting

- Using natural air conditioning systems

- Using renewable energy systems

- Energy efficient building shell design

- Ensuring sustainable transportation

\section{E. Resource conservation}

- Using durable materials

- Use of recycled materials

- Local resource use

\section{F. Water conservation}

- Landscape arrangement suitable for the region

- Waste water control

- Rainwater use

\section{G. Ecosystem protection}

- Ecosystem Protection

- Protection of natural habitats

- Protection of green tissue ratio

- Efficient use of land and urban agriculture

- Recyclable waste management

Ecological design; is the integration of the built environment (from source to production, from use to demolition) in harmony with the natural environment. From the existence of the building to its use, to the completion of its life and its extinction, the less energy it has on the natural environment in terms of the energy it uses in all phases, it is ecological. Ecological layout design should also be considered as the least resource requirement, which is the most accurately positioned in accordance with the ecological and sustainable criteria taken during the design phase, by evaluating the environmental data.

\subsection{Results}

Unplanned construction that negatively affects the living environment and the natural environment, which is the living space, structural wastes that occur during the construction of the buildings, inefficient energy and water usage during the use phase cause pollution and decrease in natural resources. In order to avoid resource shortages in the future, ecological design principles should be applied regionally, not structurally. In this way, energy and natural resource savings can be achieved on a large scale, and well-established solutions for reducing pollution rate can be offered. In order to achieve long-term and productive results in the natural environment in line with ecological criteria, local texture and topography analyzes made during the design phase should be carried out. Decisions should be made to protect energy, water, natural resources and ecosystems, and design and material choices should be made that will leave the least ecological footprint in the natural environment. In this way, ecological design criteria can become an ecological lifestyle, and changes to protect the environmental resources starting from the regional can include cities and countries [21,22].

\section{Conclusion}

Urgent sheltering needs are required for many people after wars, emergencies and natural events that take place in the world. They had to accept the conditions of housing in unhealthy living conditions and working in unsafe 
work areas. Limited natural resources and waste of all structural applications require careful steps. It should also be valid in times of crisis such as living ecologically, producing ecological solutions, making environmentalist suggestions under all circumstances, emergency situations, after a disaster, sudden migration increase. For this reason, ecological residential area project that is environmentally sensitive and self-sufficient is recommended in places where the user group is refugees.

\section{References}

[1] C. Denpaipoon and H. Kanegae, "Compact city strategy of Bangkok mega-city", Manusya: Journal of Humanities, vol. 11, no. 2, pp: 38-55, 2008.

[2] S. Sinmaz, "The Concept of Smart Settlement and Its Basic Principles in the Framework of Emerging Planning Approaches", Megaron Magazine, vol. 8, no. 2, pp: 79-80, 2013.

[3] K. E. Battal, "A Different View on the Concept of Sustainable City: Slow Cities (Cittaslow)", Paradox Economy, Sociology and Politics Magazine, vol. 8, no. 1, pp: 86-89, 2012.

[4] https://10layn.com/10-maddede-ekokoy-nedir/, (Access: 08.02.2019).

[5] http://www.webnaturel.com/eko-koy-nedir,ID 1512.html, (Access: 08.02.2019).

[6] F. Terzi and M. Ocakçı, "The Future of Cities: Smart Cities", Istanbul Technical University Publication, File: Smart Cities, Number: vol. 77, pp: 10-15, 2017.

[7] Z. Çetinkaya and A. Ciravoğlu, "Comparison of Sustainable Settlement Models: Eco-City and Slow City", Ideal Kent Magazine, no. 18, pp: 8-10, 2016.

[8] M. A. Mir and P. J. Armstrong, "Green Design of Residential High-Rise Buildings in Livable Cities", IBS/NAHB Symposium, Orlando, FL, pp: 5-6, 2008.

[9] T. Özçuhadar, "Investigation of Energy Efficient Design for Sustainable Environment in the Life Cycle Process", Master Thesis, Istanbul Technical University, pp: 16-20, 2007.

[10] http://gaziantepekolojikbina.com.tr/ekolojik-kent.html, (Access: 25.12.2017)

[11] http://www.nilufer.bel.tr/dosya yoneticisi/icerik/ekokent.pdf, (Access: 25.12.2017)

[12] http://sbpturkiye.com/eko-kent-modeli.html, (Access: 25.06.2019)

[13] F. Terzi, "Ecological Settlement Planning and Design: Example of Eskişehir Kocakır Reserve Building Area", Kentli Magazine, July-August-September, pp: 79-82, 2016.

[14] http://www.34volt.com/eskisehir-e-turkiye-ye-ornek-olacak-75-bin-nufuslu-super-kent-kuruluyorhaberi-340640/, (Access: 25.12.2017)

[15] https://www.tianjinecocity.gov.sg/, (Access: 25.06.2019)

[16] https://www.smartcitiesdive.com/ex/sustainablecitiescollective/words-most-successful-modelsustainable-urban-development/229316/, (Access: 25.12.2017)

[17] https://www.smartcitiesdive.com/ex/sustainablecitiescollective/words-most-successful-modelsustainable-urban-development/229316/, (Access: 25.12.2017)

[18] http://www.guallart.com/projects/sociopolis, (Access: 25.12.2017)

[19] S. Roaf S, Ecohouse: A Design Guide, Architectural Press, Oxford, 2001.

[20] M. Guzowski, “Towards Zero Energy Architecture - New Solar Energy Design”, Translated by: Tağmat T.S. and Güçmen N., YEM Publishing, Istanbul, pp: 49-58, 2010.

[21] G. L. Wade and J. T. Midcap, "Xeriscape: A Guide to Developing a Water-Wise Landscape", Cooperative Extension, The University of Georgia College of Agricultural and Environmental Sciences, pp: $1,2010$.

[22] S. Schimsch, T. Boermans, D. Kretschmer, M. Offermann, A. John, "For U-Value Map Turkey: Energy Performance of Buildings Directive (EPBD) Implementation of Comparative Methodology Oriented Cost-Effectiveness in the Context", Ecofys GmbH Working Report, Izoder, Istanbul, 2016. 